\title{
Vices and criminality: a social and legal assessment
}

\author{
Yury Truntsevsky ${ }^{1}$, Vyacheslav Sevalnev ${ }^{1}$, Tatiana Chursina $^{1 *}$, and Oleg Karpovich ${ }^{2}$ \\ ${ }^{1}$ Institute of Legislation and Comparative Law under the Government of the Russian Federation, \\ Cheremushkinskaya str., 34, Moscow, 117218, Russia \\ ${ }^{2}$ Diplomatic Academy of Ministry of Foreign Affairs of the Russian Federation, Ostozhenka str., \\ 53/2, Moscow, 119021, Russia
}

\begin{abstract}
The article presents a philosophical and legal study of relationship between the concepts of vice, sin and crime. On the basis of modern criminological analysis, the authors conclude that the main cause of crime lies in the objective existence of human vices associated with the weakness of human nature. As a part of the study of criminal cases, the authors formulated a generalized criminological portrait of a personality of a police officer who commits corruption crimes. The authors argue that criminalization of a personality goes through several successive stages: vice, passion, sin (immoral behavior, administratively punishable act, and the highest degree is a crime). The authors propose to consider corruption from two sides: 1) as an independent personal vice and 2) as a reflection (result) of the vices of society. The corruption crime is examined by using the triangle of Donald Craessy. On the basis of this approach, the authors argue that social causes alone do not trigger corruption behavior. Only vices push an offender to corrupt behavior. As a mean of preventing of official misconduct, the authors propose moral and ethical standards of official conduct.
\end{abstract}

\section{Introduction}

Insurance Sociological science definitely satisfies the need for knowledge oriented to an accurate and deep description of real social phenomena and processes. So, developing a theory of analysis of social interaction, Emil Durkheim defined the method of sociology. He argued that social facts should be considered as "things", objectively and impartially as possible, revealing the logic of their existence. According to Durkheim's idea, social facts should be supported by other social facts. This approach develops the ideas, previously laid down by the founder of sociology, O. Conte, that true science should be based on observable, fixed, and repeating phenomena and trends. Considering the existence of crime and corruption as a social fact, it should be justified by their social character and generally accepted norms of interaction between members of society, the values that guide them in real life situations.

There are three main approaches to understanding crime:

*Corresponding author: a.copytowa@yandex.ru 
- anthropological (the reasons lie in human nature);

- sociological (the causes of crime come from the social disorganization of society);

- metaphysical (a crime is a violation of natural laws of life).

\section{Methods}

Other classification can show two main approaches:

1) Biological theories.

2) Sociological theories.

On the one hand, many scientists are concentrating all their attention on the internal, physiological starting mechanism of human behavior (natural born offender, genetic predisposition), ignoring the ability of social factors to effectively regulate human actions. On the other hand, there are concepts that completely ignore the internal conditioning of behavior and imagine a person as just a "product" of external conditions of existence, training, education.

In criminal sociology, this problem is called the "correlation of the social and biological in the personality of the criminal", which dealt with the question, what is decisive: social or biological in the person who committed the crime, from the point of view of understanding his criminal behavior; secondly, what are the limits of the study in criminology of the biomedical characteristics of criminals.

The question of relationship between social and biological in the personality of the criminal is one of the most difficult questions. It is of fundamental importance for explaining the motivation and causes of human behavior and its nature, for solving essentially all criminological problems.

The biological origin is closely intertwined with the social in such properties of human personality as emotions, character traits, characteristics of nervous system, will, memory, abilities, etc. The biological nature of gender and age differences, physical and sometimes mental state of a person are beyond argument.

The mechanism of interaction between social and biological is not reduced to a simple addition of social and hereditary programs of behavior. This is a single process where social and biological (environment and heredity) act in close interaction.

\section{Results}

It is well known that the main cause of crime is the existence of human vices (a vice is a moral, spiritual deficiency; everything that is contrary to the truth and ultimate good; evil and mendacity as human qualities; every moral distortion; cruel intentions). And while alcohol abuse is a common vice among the people and stealing and lying are known to be the crudest vices, self-love is a natural-born vice.

Prominent researcher Proleev S.V. has singled out 105 vices:

1. Aggressiveness. 2. Knavery. 3. Bragging. 4. Lack of will.5. Absense of morals 6. Ruthlessness. 7. Inhumanity. 8. Squeamishness. 9. Treachery. 10. Grumbling. 11. Irascibility. 12. Arrogance. 13. Stupidity. 14. Anger. 15. Pride. 16. Rudeness. 17. Prevarication.18. Children's depravity. 19. Greed. 20. Cruelty 21. Envy.22. Fawning. 23. Longing. 24. Malice. 25. Vengefulness. 26. Animosity. 27. Treason. 28. Capriciousness. 29. Cunning. 30. Selfishness. 31. Inertness. 32. Frivolity. 33. Laziness. 34. Falsity. 35. Hypocrisy. 36. Curiosity. 37. Flattery. 38. Cowardice. 39. Pettiness. 40. Suspicion. 41. Vindictiveness. 42. Insolence. 43. Insolency. 44. Intrusiveness. 45. Impermanence. 46. Ingratitude. 47. Ignorance. 48. Unknown-vice. 49. Infidelity. 50. Incuriousity. 51. Untidiness. 52. Inconsistency. 53. Impermanence. 54. Indecisiveness. 55. Immodesty. 56. 
Injustice. 57. Intolerance. 58. Disrespect. 59. Recklessness. 60. Pedantry. 61. Pessimism. 62. Cheating. 63. Suspicion. 64. Villany. 65. Adulation. 66. Vulgarity. 67. Servilism. 68. Indifference. 69. Irritability. 70. Absent-mindedness. 71. Jealousy. 72. Shyness. 73. Narcissism. 74. Conceit. 75. Arrogance. 76. Grumpiness. 77. Sentimentality. 78. Obscenity 79. Stinginess. 80. Quarrelling. 81. Voluptuousness. 82. Treacle. 83. Snobbery. 84. Bigotry. 85. Refractoriness. 86. Fussiness. 87. Idle-talk. 88. Barratry. 89. Recreancy. 90. Dumbness. 91. Vanity. 92. Assentation. 93. Surliness. 94. Stubbornness. 95. Audacity. 96. Hypocrisy. 97. Boastfulness. 98. Dullness. 99. Cynicism. 100. Self-indulgence. 101. Obduracy. 102. Ambition. 103. Stiffness. 104. Gluttony. 105. Egoism.

In our opinion, the main types of vices are of public nature and related to personal reasons. Taking into account the 105 flaws listed above, they can be represented in following table (Table 1).

Table 1. Types of vices

\begin{tabular}{|l|l|}
\hline Public vices & \multirow{1}{*}{ Personal vices } \\
\hline Alcohol abuse & \multirow{2}{*}{$7,20,35,66,68,78,81,96,99,101,104$} \\
\hline Drug addiction & \\
\hline Pornography & \\
\hline Prostitution & \\
\cline { 1 - 1 } Homelessness & \\
\cline { 1 - 2 } $\begin{array}{l}\text { Exploitation (no will to work, living } \\
\text { at someone else's expense) }\end{array}$ & \\
\hline
\end{tabular}

The survey on the question: "What vices prevail in modern society?" conducted by us showed the following: cruelty, frivolity, indifference, anger, cowardice, vanity, irresponsibility, envy, greed, hypocrisy.

The Government of Russian Federation adopted Decree № 662 of May 25, 2019 “On the Approval of the Methodology for Conducting Sociological Research in order to Assess the Level of Corruption in the Subjects of Russian Federation" which establishes the research rules and is also recommended to senior officials (heads of the highest executive bodies of state power) of subjects of Russian Federation to ensure the annual conduct of sociological research in order to assess the level of corruption in the subjects of Russian Federation.

Such a study focuses on the problems of "everyday" corruption that occurs during the interaction of citizens and government officials, including provision of state (municipal) services, and "business" corruption that arises from the interaction of government and business representatives.

At the same time, only one point among dozens of questions concerns the explanation of the causes of corruption in questionnaire of a sociological survey in order to assess the level of corruption in the subject of Russian Federation: "point 24. What do you think is the main reason for the spread of bribery and corruption in Russia? (one answer option):

1) complex, contradictory legislation;

2) prevailing traditions in society, features of culture, mentality;

3) greed of officials;

4) other (specify what exactly);

5) I do not know, I find it difficult to answer.

Modern criminologists include following factors in the majority of causes of corruption:

- increased tolerance of Russian state and society to corruption and corrupt officials;

- lack of legislation in the country to implement an effective system of anti-corruption measures; 
- presence of pathological components in spontaneously forming dominant ideology (both at the level of public consciousness and at the level of social practice), essence of which is as follows:

a) priority of individual interests over public and state ones;

b) absolute dominance of comfort and various forms of material consumption in the value system;

c) honesty, moral purity are quite firmly linked with poverty, outsiderness, and these qualities begin to gradually fall in the public consciousness into the categories of unattractive, unacceptable, shameful;

d) principles of "money does not smell", "wealth at all costs" rather successfully implemented among the elite sphere, begin to dominate in society.

- Unacceptable level of material incentives for law enforcement officers in terms of active anti-corruption activities, insufficient level of their training and support.

- low living standards of persons with higher education;

- insufficient development of various civil society institutions, lack of experience in non-governmental fighting against corruption.

We will return to the problem of determining the significance of causes of corruption crime in the behavior of an individual a little later.

What should be called a vice, a flaw or just a weakness, apparently, depends on the specific situation. We shall consider all human vices (non-virtues) cited in the work of Proleev S.V. The analysis of such defects has allowed to correlate them with causes of specific types of criminal behavior occurring and repeating massively among the population (types of crime).

Modern criminological analysis, which is an area of applied social research, allows us to explore the processes taking place in society with the help of specific data: level, volume, dynamics, structure of crime. We will try to examine the structure of crime from the perspective of its most important determinants - human vices.

Vices themselves, in the fair opinion of L. Spooner, are not crimes. Vices are actions by which a person harms himself or his property. Crimes are actions by which one person harms another person or someone's property. In addition, vices are constantly being reevaluated.

And although Thomas Akvinsky, for example, objected to the criminalization of most vices because this would make most people criminals. He foresaw the criminalization of such moral defects as alcohol abuse, drug abuse, sexual immorality, etc. which are not necessarily harmful towards other people or their property, because they are unjust and lead to great sins.

Thus, the seven deadly sins could well come from ambition, indifference, pride in good work, righteous anger, healthy sexuality, and enjoying good food. It all depends on their degree.

A vice implies moral ambivalence, a behavior that a person can enjoy and simultaneously regret. For example, laws on illicit drug use, participation in certain types of gambling, selling or buying sexual services, multiplicity of marriages are often characterized as being applied to behavior that is harmless, harmful only to the performer, or others, but done with mutual consent.

Laws prohibiting such behavior are considered objectionable (at least by liberals) because they are moralistic (in the sense that they criminalize behavior exclusively or mainly because it is inherently wrong or sinful, and not because of its negative impact on someone). People who love gambling, marijuana and prostitution often advocate for their legalization and even in cases where the majority is against such legalization, laws can challenge them. Or, for example, Western Europe accuses our country, Belarus, Armenia, Azerbaijan of discrimination against gays, lesbians, the LGBT community and the gay 
parade; and of the federal legislation of Russia raising young people with respect for family values - the threat of administrative punishment for propaganda of non-traditional sexual relations between minors.

Undoubtedly, the law was created for a number of people, most of whom are perfectly virtuous. That is why the laws do not prohibit all vices, with no virtue, but punish only for the most violent of them, from which the majority can abstain; these are mainly those harming others i.e. the law prohibits murder, theft, etc.

St. Thomas repeated the truth: the suppression of vices can lead to more evil: "[Human rights] do not place on many imperfect people the burden of those who are already virtuous. Otherwise, these imperfects, incapable of keeping such commandments, would have escaped into even greater evil".

At the same time, a crime cannot be called a crime without criminal intent, i.e., without an intention to invade private life, steal property, etc. Such criminal intent is formed by human vices.

Which environment encourages the appearance and spreading of human vices among the population? In our opinion it is a decrease in the level of morality. Therefore, according to Archpriest Artemy Vladimirov, universal notions of duty, honor, conscience, responsibility, loyalty become unclear (non-obvious), and society suffers from this under the weight of its own immorality. If we paraphrase the words of Evangelist Matthew about human love, "due to the increase in lawlessness" aside from love, other virtues in the society have also lost their appeal.

Morality is one of the most important factors in social life, social development and progress. However, other values "are currently in demand": career and fame, wealth and adaptability, "glamorous life" and debauchery. The fact that this is happening in our modern society shows that people are under the oppression of immorality, and seem to be lost in this state.

Analyzing the connection between vices and specific crimes, we can conclude that a large proportion of violent crimes committed among men are committed under the influence of alcohol. This cannot be said about non-violent crimes.

On the other hand, the "big" crimes committed in the world are generally caused by greed and ambition, i.e. wars waged by governments to plunder, enslave, and destroy humanity.

Mercenary crimes are equally caused by greed and ambition, they re not committed impulsively, but with calculation. Only a "clear" head allows scammers to commit crimes. Individuals under the influence of intoxicating drinks aren't well adapted to and are completely unequal to the successful practices of these scammers. Drunks are the most careless, the least successful, the least effective and least dangerous of all criminals. "Successful" robbers, bandits, thieves, falsifiers, and counterfeiters are all but reckless drinkers, their "business" is too dangerous to take the risks that drinking might incur.

If we take a look at the structure of crime, we can single out its main types in relation to human vices (Table 2).

Table 2. The ratio of types of crime and vices

\begin{tabular}{|l|l|}
\hline Types of crime & Human vices \\
\hline Violent & $1,6,7,9,11,14,16,20,24,25,41,69,71,95,99,105$ \\
\hline Mercenary & $2,19,21,30,62,64,99,104,105$ \\
\hline Reckless & $32,33,38,54,59,68,69,70,72,75,86,89$ \\
\hline Moral & $26,34,66,71,78,80,81$ \\
\hline Official, corruptionbased & $\begin{array}{l}21,29,35,64,65,67,81,91,92,99,105 \\
\text { + All evils of mercenary and reckless crimes }\end{array}$ \\
\hline
\end{tabular}


The table shows that violent crime (murder, injury, etc.) is highly perverse, but the most vicious crime is corruption with its ability to manifest human weaknesses.

According to the Criminal Code of Russian Federation, responsibility for the most dangerous corruption deeds - bribery in a profit-making organization is provided for in the following articles: Article 204 - Bribery in a Profit-Making Organisation, Article 204.1 Mediation in Bribery in a Profit-Making Organisation, Article 204.2 - Petty Bribery in a Profit-Making Organisation, Article 290 - Bribe-Taking, Art.291- Bribe-Giving, Art.291.1 - Mediation in Bribery, Art.291.2 - Petty Bribery.

Fig. 1. shows the total number of this type of corruption crimes recorded in Russia over the past 10 years.

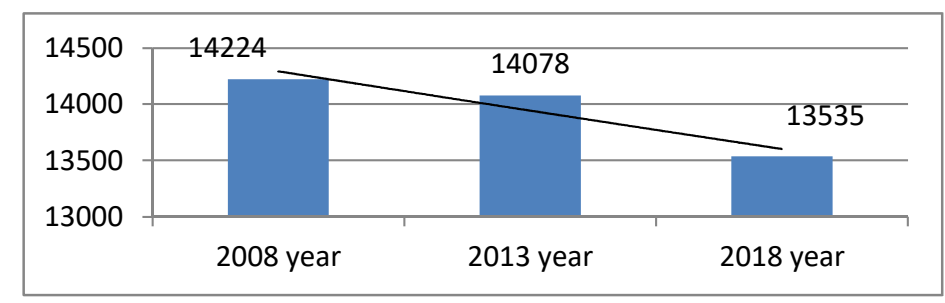

Fig. 1. The total number of bribery and bribery in a profit-making organisationfor 10 years in Russia (data from form 1-ЕГC USS for 2008, 2013 and 2018) [18]

Given the general trend of a decrease in the number of such crimes by 2018 , as shown in Table 3, petty bribery in a profit-making organisation (articles 291.2 and 204.2 of the Criminal Code of Russian Federation, respectively) are of the largest number this year (see Fig. 2). Moreover, these crimes were separated from general bribery and bribery in a profitmaking organisation - the articles were enforced by Federal Law № 342-FZ.of July 3, 2016

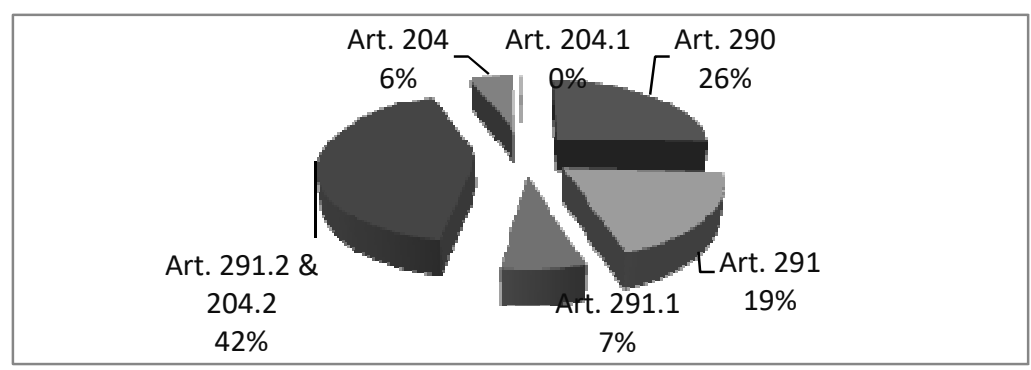

Fig. 2. The structure of the crime of bribery and bribery in a profit-making organisation in Russia in 2018

According to the data of FOMnibus Foundation, 45\% of Russians believe the level of corruption in Russia is higher than in most European countries. Young people and people with higher education have this opinion much more often than others (indicators in these groups - 55\%). Most often, people attribute this to the fact that "corruption is encouraged by the state", "there is no punishment and control", "the authorities themselves are corrupt", "Russian cannot but take - people are like that": 


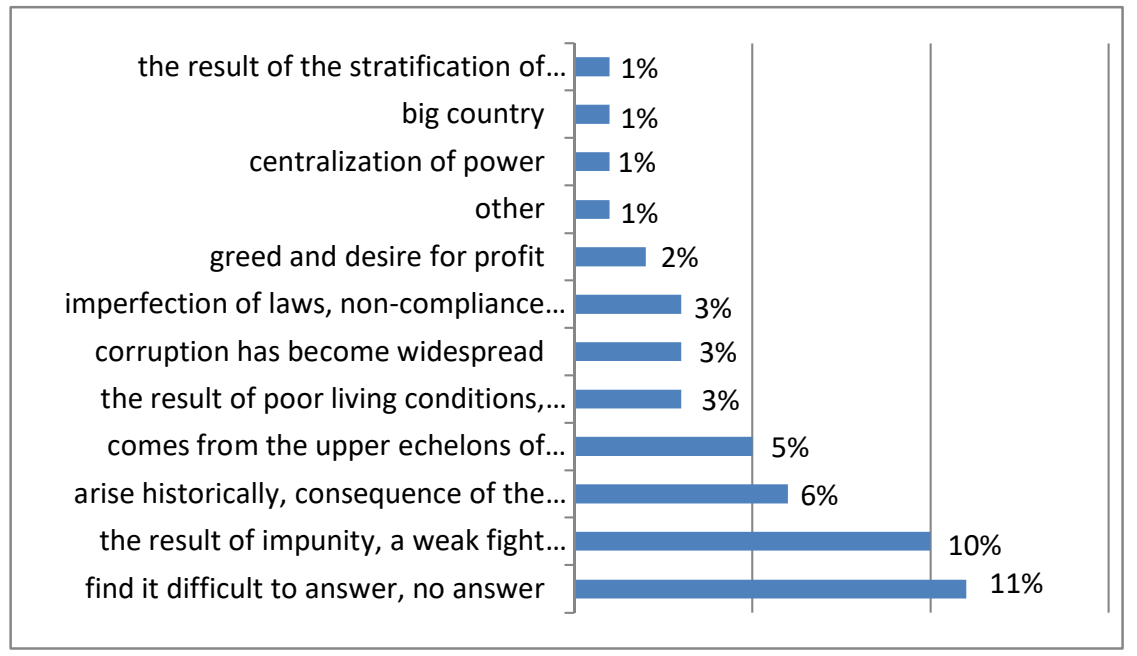

Fig. 3. The results of a survey of citizens on causes of corruption

At the same time, whatever the types of corruption manifestations, regardless of the sphere of their existence, whether it is the interaction of ordinary citizens and officials, government and business, the basis of these interactions is an individual who belongs to a certain social layer, adheres to his own cultural values, evaluates a situation involving consequences, wishing for the results to occur, making a choice of actions, making a decision on their implementation, etc.

As part of the study of criminal cases, we formulated a generalized criminological portrait of the personality of a police officer who commits corruption crimes. This is the overwhelming majority (2/3) of males, aged 21 to 35 years, with a higher and incomplete higher education, mostly with legal, pedagogical and technical education, usually married, with mercenary motives predominates. Additional features of the criminological portrait are: an increase in the intensity of corrupt activities as career length increases and the prevailing motive for personal enrichment and improvement of one's own financial situation. For the most part, corrupt officials quite often are not very well child guided, and their education is purchased. Corruptionists are not alike, as is our entire society. But for the most part they are rude, arrogant and narcissistic, behave indiscreetly in clothes, in everyday life, but normally behave only in front of the higher authorities.

The so-called "careerist" motives can be attributed to the group of mercenary vices, when the acquisition of a certain post by an individual is perceived as a source of enrichment.

Conformist motives show the individual's unwillingness to stand out from the crowd and become the center of attention, the desire to "be like everyone else", fear of change, unwillingness to take initiative and solve problems, fear of responsibility for one's own actions. Official misconduct is caused by the unwillingness to "spoil relations with colleagues", the desire to please authorities or blindly follow the example of colleagues.

Thus, human vices themselves should not be recognized as crimes, however, it is vices that push the person to commit them and form criminal motivation. The most "vicious" in terms of their occurrence are malfeasance and crimes of a corruption nature, which makes it possible to single out moral and ethical standards of official conduct as the main means of preventing malfeasance. 


\section{Discussion}

Although society requires a core of regulatory consensus, we often find significant duality of peripheral norms (rights and morals). A vice representing both pleasure and evil reflects moral ambivalence located on the periphery. Attitude toward a vice tends to change and such changes can be dramatic, as has happened in the case of gambling and drugs in the last two or three decades. At the same time, sociological understanding shows that such decisions depend more on ideology based on cultural contexts and symbolic functions than on scientific hypotheses and empirical studies.

In the context of the ideas expressed above, it is quite interesting to take a look at the question of relationship between such phenomena as vices and sin, crime and offence.

It is possible to hypothesize that human sins are a particular case of perversity. It also may be possible that depravity acts as the ability of a person to sin.

To test this hypothesis, we must understand the relationship between sin and crime.

So, $\sin$ (amartia (greek) - a mistake, a miss past the target) is damage to human nature, a disease of the soul.

Sin is the primary quality of human spirituality and can be perceived as a cowardly refusal of the human spirit to strive for the supreme - transcendence, as daily weakness.

The mechanism of criminal (corruptional in our research) behavior includes such a personality trait as depravity - a tendency to vice, immorality.

Sin is a conscious act, an action that harms the sinner himself and other people.

Passion is what drives our vices to sin, and from it to crime. So, passion is a steady and extremely strong attraction of the human will to a particular sin, and as a result to a crime. This attraction develops through the repeated commission of this sin until, at one terrible moment, a person suddenly realizes that he is no longer in control of his desire and now vice versa - this desire gains complete dominance over him. The most obvious example of such a dependence is drug addiction: addicted to drug poison, people spend a lot of money first on buying their favorite potion, then even more money on trying to completely abandon the drug ("jump off"), but alas! - not everyone succeeds in getting rid of this passion.

Approximately according to the same pattern, corrupt behavior of people who have the corresponding vices (voluptuousness, love of money, popularity, etc. Voluptuousness refers to everything that somehow sweetens the human body and soul; to love money - money and all the joys that you can buy; to popularity - honor and respect among people, power, fame, enjoyment of praise or at least the public mention of your name.): "And I would like to quit - but it doesn't work out already. Passion requires violating anti-corruption and ethical standards."

The implementation of these corruption vices is expressed in fatal passion, and this is already a "vice in action". A vice becomes an inalienable quality of a human person: moral inferiority, abnormal behavior, sinfulness of life that a person is no longer able to hide, and therefore it becomes visible to an outsider. So, the criminalization of personality goes through several consecutive steps: depravity - passion - sin (immoral behavior is an administratively punishable act and the highest degree is a crime). 


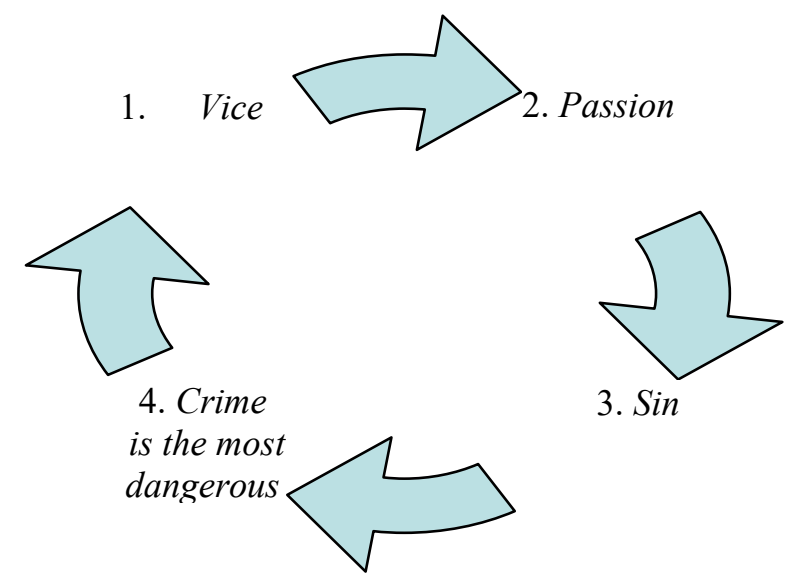

Fig. 4. Stages (cycle) of criminalization of personality

Thus, criminality is a reflection of vices of mankind. A similar cycle of criminalization of personality is proved by the law of reflection, when the external reflects the internal. And if crime is a reflection of personal vices, then crime is a reflection of human vices.

What is corruption in its essence? In the literal translation from the Latin language, it means the following: to damage, squander, destroy, deceive, shame, dishonor. Based on this definition, corruption can be considered both as an independent personal vice and as a reflection (result) of the vices of society, government and human.

Corruption crime, reflecting vices, can be represented using the triangle of Donald Crassi [1], which allows to create an understanding of motivation for committing illegal actions.

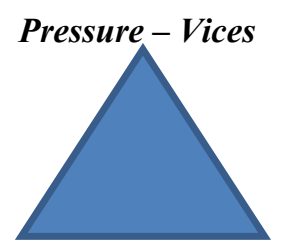

\section{Justification Opportunity}

Fig. 5. Corruption crime

The first element of the triangle (originally used by D. Crassie in relation to fraud) is pressure, which is expressed primarily in human needs. Such vices as greed, desire to live better than others motivate and stimulate an individual to participate in corruption.

It can be seen from this figure that social causes alone do not trigger corruption behavior - only vices push the offender to corrupt behavior, which he justifies in various ways. Therefore, a person remains in captivity of his vices and passions, does not want to get rid of them. His vices and his passions give him pleasure. A highly corrupt official stops being ashamed of his vices, begins to flaunt them (demonstrate) and defend the rights to his vices. The so called causes of the crimes in criminology that we mentioned above, within the framework of this triangle can be attributed to opportunities, for example, a bribe is possible when personnel (staff) control over the performance of official duties by employees in the state body is weak, that allows them to take bribes etc. At the same time, even in such a poorly controlled team, most employees will not take bribes, because unlike corrupt officials they don't have a desire to realize vices, since they either not peculiar (as a result of legal and spiritual education), or their legitimate behavior is the result of their personal will (legal culture). 
Vices cannot be prohibited. Another point is that vices are not necessary to encourage. When a person is diagnosed with a heart defect, for example, they are referred to a cardiology clinic. But where should a person with moral defects go? You cannot use disinfecting solution, and they themselves will not resolve. And since there is no clinic for social vices, then a person needs to be able to overcome his vices, to be able to cope with them.

The principle of combining legal and non-legal means serves to ensure a comprehensive crime response. By the fair statement of T.Ya. Khabrieva, "the rule of law does not cover all aspects of human relationships. Ethical norms affect participants of public relations along with legal regulators. Moreover, they are able to replenish legislation in matters of resolving moral conflicts". "A significant role in formation of moral foundations of the behavior of state (municipal) employees is occupied by ethical norms, which have been recognized by the state by enshrining in normative legal acts. Ethical norms offer a certain style of behavior, contain restrictions, recommendations and prohibitions". That is why one of the objectives of activities of the National Anti- Corruption Plan for 2016-2017 was chosen to be increasing the influence of ethical (moral) standards in ensuring compliance with anti-corruption requirements by individuals replacing government posts in Russian Federation, state posts of constituent entities of Russian Federation, municipal posts and municipal service.

Formation of an anti-corruption culture requires that citizens step by step develop a value system that allows for:

- understanding corruption as a phenomenon;

- creating a negative attitude towards corruption;

- being aware of the anti-corruption standard of conduct;

- acquiring the ability to solve the problems of illegal activities, based on legal norms, morality and ethics.

\section{Conclusion}

Thus, it is necessary to summarize some of the thoughts expressed in this article:

1. The main cause of crime is the existence of human vices, the fertile soil for which is a decrease in the level of public morality.

2. Criminal laws do not prohibit all vices, but punish only the most violent of them. The most vicious in its multifaceted manifestations of human vices is official and corruption crime.

3. Moral and ethical standards of official conduct are the main means of preventing official malfeasance.

4. Human sins are a particular case of depravity, with depravity being the person's ability to sin.

5. Vice is the basis of the crime, is the reason and the cause for its commission. Vice and crime can be correlated as the cause and external consequence.

6. The spiritual revival of religious values, not prohibited by the law of religious denominations, will greatly contribute to the reduction of crime.

\section{References}

1. A. Hutahaean, E. Indarti, Journal of Money Laundering Control 23(1), 136-154 (2020). DOI: 10.1108/JMLC-12-2018-0075

2. O. Stöckel, Urologe 58(8), 904-909 (2019). DOI: 10.1007/s00120-019-0968-4 
3. N. Fazlur Rahman, Journal of Money Laundering Control 22(3), 576-590 (2019). DOI: 10.1108/JMLC-09-2018-0059

4. D. Freire, Latin American Perspectives 46(4), 230-244 (2019). DOI: $10.1177 / 0094582 X 19846519$

5. Stuart P. Green. Criminal Law and Philosophy 9(3), 561-576 (2015)

6. E.S. Dubonosov, N.V. Bugaevskaya, T.S. Volchetskaia, V.N. Vlasenko, Journal of Siberian Federal University - Humanities and Social Sciences 12(6), 918-924 (2019). DOI: $10.17516 / 1997-1370-0429$

7. A.N. Varygin, E.V. Chervonnykh, A.S. Klementev, P.A. Pimenov, Russian journal of criminology 13(3), 506-518 (2019). DOI: 10.17150/2500-4255.2019.13(3).506-518

8. Yu.V. Truntsevsky, LGBT Communities Reached High International Stands: Traditional Spiritual and Moral Values Have Always Been and Will Remain Unchanged in Russia 03/15/2018. Available at: https://www.zakonia.ru/analytics/57/53839 [Accessed:11.07.2019]

9. , V. Lez'Er, N. Semerianova, A. Kopytova, Y. Truntsevsky, E3S Web of Conferences 2019 110, 02093 (2019). DOI: 10.1051/e3sconf/201911002093

10. Yu.V. Truntsevsky, The interaction of law and morality: proceedings of an international scientific conference (Moscow: Publishing House Mosk. humanity. University; 2014)

11. V.V. Sevalnev, Yu.V. Truntsevsky, A.M.Tsirin, Legal Regulation of Combating Corruption in China: Scientific and Practical Guide (Editor-in-Chief T.Y. Khabrieva. The Institute of Legislation and Comparative Law under the Government of the Russian Federation, 2018)

12. Decree of the President of the Russian Federation dated April 1, 2016 No. 147 « About the National Anti-Corruption Plan for 2016-2017»// Legislation meeting RF. № 14, Art. 1985 (2016).

13. V.A. Lez'Er, N.A. Semeryanova, A.V. Kopytova, MATEC Web of Conferences, 239, 04027 (2018). DOI: 10.1051/matecconf/201823904027

14. N. Semeryanova, O. Fedorenko, A. Kopytova, MATEC Web of Conferences 239, 04013 (2018). DOI: 10.1051/matecconf/201823904013

15. D. Izvin, V. Lez'Er, A. Kopytova, MATEC Web of Conferences 170, 01065 (2018). DOI: $10.1051 /$ matecconf/201817001065

16. Y.V. Truntsevsky, I.I. Lukiny, A.V. Sumachev, A.V. Kopytova, MATEC Web of Conferences 170, 01067 (2018). DOI: 10.1051/matecconf/201817001067

17. E.E Esoimeme,.Journal of Money Laundering Control 22(2), 176-187 (2019). DOI: 10.1108/JMLC-06-2017-0021

18. A.V. Kopytova, N.S. Zotkina, I.G. Reshetnikova, MATEC Web of Conferences 239, 04012 (2018). DOI: 10.1051/matecconf/201823904012

19. M. Freckleton, Journal of Money Laundering Control 22(1), $89-96$ (2019). DOI: 10.1108/JMLC-01-2018-0006 